\title{
From Conflict to Common Ground: Why anti-trafficking can be compatible with challenging the systemic drivers of everyday abuses
}

\author{
Ella Cockbain
}

\begin{abstract}
Response to the ATR debate proposition 'It is worth undermining the anti-trafficking cause in order to more directly challenge the systems producing everyday abuses within the global economy.'
\end{abstract}

Please cite this article as: E Cockbain, 'From Conflict to Common Ground: Why anti-trafficking can be compatible with challenging the systemic drivers of everyday abuses', Anti-Trafficking Review, issue 15, 2020, pp. 155-161, https:/ / doi.org/10.14197/atr.201220159.

The sheer force of myths and misconceptions around human traffickingand 'modern slavery' - detracts from much-needed conversations about how global economic and socio-political systems foster both everyday and extreme abuses. Yet, anti-trafficking efforts in and of themselves do not represent a shared and singular cause: agendas, expressions and interventions vary markedly across different times, places and actors. ${ }^{1}$ Some anti-trafficking efforts are well informed, thoughtful, collaborative and aimed at meaningful change; others are blatantly problematic, using the guise of anti-trafficking to promote measures that harm the very groups they claim to serve. Unsurprisingly, many also fall in between these two extremes.

Across the not-for-profit sector, journalism, politics, academia and beyond, it is frustratingly common to hear widely discredited claims about trafficking repeated as if they were indisputable facts. Thus, people invested with authority blithely assert, for example, that trafficking represents the 'third most profitable

\footnotetext{
1 A Bunting and J Quirk (eds.), Contemporary Slavery: Popular rhetoric and political practice,
} University of British Columbia Press, Vancouver, 2017.

This is an open-access article distributed under the terms of the Creative Commons Attribution License (CC-BY). Under the CC-BY license, the public is free to share, adapt, and make commercial use of the work. Users must always give proper attribution to the authors and the Anti-Trafficking Review. 
organised crime' or that there are ' 40.3 million modern slaves' worldwide.' I suspect the issue here is not so much ignorance as a willingness to overlook conceptual and statistical shortcomings. A simplified and sensationalised version of trafficking commands more attention and better serves other self-interests, such as securing funding, winning popular support, or selling products and services. Yet, this overblown rhetoric ultimately fuels misleading debates around a complex issue and creates credibility problems for the entire field.

There is also a widespread tendency to exceptionalise trafficking, treating it as a neatly delineated, standalone issue involving wicked criminals and idealised victims. ${ }^{3}$ This conceptualisation naturally translates into an overwhelming focus on 'bad apples' and a concomitant neglect of the 'bad barrels' that produce them. We see this situation most clearly in the way attention and investment in anti-trafficking have coalesced around criminal justice responses, with success routinely measured in terms of the number of offenders prosecuted and/or victims assisted. ${ }^{4}$ Such interventions are important but far from sufficient; they do not address the drivers of abuse at situational (i.e. linked to the immediate environments) or systemic levels (i.e. linked to broader economic, political, and social structures). As such, the dominant approach means endlessly playing catch-up, intervening once harm is done and reaching only a fraction of those affected.

Many corporations-including ones with dubious labour rights records-have proved keen on anti-trafficking. The appeal seems to lie at least partially in an easy public relations win that requires little introspection or expensive changes to core business practices. Politicians and governments have also rallied to the anti-trafficking cause, having seemingly determined that it can often be championed (superficially, at least) without disturbing existing socio-economic and political structures. ${ }^{5}$ Universities have alsorecognised that trafficking and 'modern slavery' are fruitful topics in terms of securing research funding and attracting students, as evidenced by a proliferation of publications and the spread of dedicated new research centres, degrees, and modules. I genuinely

2 For a detailed critique of spurious claims-making around trafficking/'modern slavery', see J O'Connell Davidson, Modern Slavery: The margins of freedom, Palgrave Macmillan, Basingstoke, 2015.

3 E.g., $\mathrm{M}$ Wilson and E O'Brien, 'Constructing the Ideal Victim in the United States of America's Annual Trafficking in Persons Reports', Crime, Law and Social Change, vol. 65, issues 1-2, 2016, pp. 29-45, https://doi.org/10.1007/s10611-015-9600-8.

4 E.g., The Anti-Trafficking Monitoring Group, All Change: Preventing trafficking in the UK, Anti-Slavery International, London, 2012.

5 I de Vries et al., 'Anti-Immigration Sentiment and Public Opinion on Human Trafficking', Crime, Law and Social Change, vol. 72, issue 1, 2019, pp. 1-19, https://doi. org/10.1007/s10611-019-09838-5. 
believe that robust research evidence is needed to understand and tackle the extreme abuses of trafficking. I am well aware, however, that I have also benefitted professionally from an increased spotlight on trafficking and investment in related research.

The longer I work in this field, the more I am troubled by the ways antitrafficking can be actively harmful and help produce everyday abuses among already marginalised populations. Work framed as anti-trafficking is not necessarily driven primarily (or even at all) by a commitment to addressing inequalities and abuses. Instead, anti-trafficking can act as a convenient cover for other motives, such as promoting unpalatable laws and policies, appealing to distinct voting constituencies, or increasing influence overseas. Consequently, anti-trafficking can function as a backdoor to introduce measures constraining human and labour rights, dressed up as protection, rescue, or rehabilitation. An obvious example is the push for the so-called 'Nordic Model': a form of asymmetric criminalisation under which sexual services are legal to sell but not to buy. Despite its abject failure to deliver on its anti-trafficking promises where implemented and its well-documented harms to sex workers (such as the increased risk of violence), ${ }^{6}$ politicians and prostitution abolitionists continue to abuse anti-trafficking logic to push for the model's adoption elsewhere. Other anti-trafficking measures that have attracted criticism for harming marginalised groups include immigration raids framed as 'welfare checks', forced 'rescues' of reluctant 'victims', bans on advertising sexual services online, and 'spot the signs' campaigns that encourage racial profiling and uncritical citizen surveillance.?

It is clearly imperative to engage with the tensions, limitations, and harms of anti-trafficking. Nevertheless, I think it would be misguided to dismiss the entire enterprise outright. The first main reason why is that the anti-trafficking frame has a demonstrable ability to increase the visibility and prioritisation of extreme abuses. That is positive in itself, regardless of whether this frame also advances understanding of more everyday abuses. To illustrate, in our research

6 L Platt, et al., 'Associations between Sex Work Laws and Sex Workers' Health: A systematic review and meta-analysis of quantitative and qualitative studies', PLoS medicine, vol. 15, issue 12, 2018, https://doi.org/10.1371/journal.pmed.1002680; G Ellison, C Ní Dhónaill, and E Early, A Review of the Criminalisation of the Payment for Sexual Services in Northern Ireland, Queens University Belfast, Belfast, 2019.

7 See, e.g., M Smith and J Mac, Revolting Prostitutes: The fight for sex workers' rights, Verso, London, 2018; A Volodko, E Cockbain, and B Kleinberg, "'Spotting the Signs" of Trafficking Recruitment Online: Exploring the characteristics of advertisements targeted at migrant job-seekers', Trends in Organized Crime, vol. 23, 2020, pp. 7-35, https://doi.org/10.1007/s12117-019-09376-5. 
into labour trafficking in the $\mathrm{UK}^{8}{ }^{8} \mathrm{I}$ encountered much evidence of police (and other authorities) misunderstanding and minimising extreme labour abuses. For example, various people later officially designated as labour trafficking victims initially reported exploitative labour situations to the police, only to be told it was 'just' a civil matter and to seek help elsewhere. Some such individuals ended up desperately trying to walk along motorways to reach their embassies in London. I would hope such dismissive responses are less likely now that a scathing national inspection of police responses to 'modern slavery" prompted a multimillion-pound investment in improving them. These changes themselves followed heightened political interest in trafficking/'modern slavery' and a push for a greater focus on abuses within the regular labour market. ${ }^{10}$ An antitrafficking lens can also increase attention to abuses occurring within the informal economy. In the UK, for example, re-framing sexual and criminal exploitation of children in terms of trafficking/'modern slavery' has helped attract interest and investment in tackling these complex and long-neglected issues. ${ }^{11}$ If fewer children are now dismissed and criminalised as consenting 'child prostitutes' or 'drug runners', then I would argue that this represents progress. ${ }^{12}$ The diversity of examples here highlights another important point: trafficking is a broad and varied phenomenon and disaggregating it into meaningful components helps target responses towards their specific characteristics and drivers. ${ }^{13}$ Importantly, law enforcement alone cannot tackle trafficking and exploitation, yet vital

8 See, e.g., E Cockbain, K Bowers, and L Vernon, 'Using Law Enforcement Data in Trafficking Research', in J Winterdyk and J Jones (eds.), The Palgrave International Handbook of Human Trafficking, Palgrave Macmillan, Basingstoke, 2019.

9 Her Majesty's Inspectorate of Constabulary and Fire and Rescue Services (HMICFRS), Stolen Freedom: The policing response to modern slavery and human trafficking, London, 2017.

10 C Robinson, 'Policy and Practice: Claiming space for labour rights within the United Kingdom modern slavery crusade, Anti-Trafficking Review, issue 5, 2015, pp. 129-143, https://doi.org/10.14197/atr.20121558.

11 E Cockbain, Offender and Victim Networks in Human Trafficking, Routledge, Abingdon, 2018; E Cockbain and K Olver, 'Child Trafficking: Characteristics, complexities and challenges', in I Bryce, W Petherick, and Y Robinson (eds.), Child Abuse and Neglect: Forensic issues in evidence, impact and management, Elsevier, New York, 2019, pp. 95-116.

12 The dismissal of exploited children in such terms by various authority figures has long been documented in the UK. See, e.g., Cockbain and Olver.

13 See, e.g., E Cockbain and K Bowers, 'Human Trafficking for Sex, Labour and Domestic Servitude: How do key trafficking types compare and what are their predictors?', Crime, Law and Social Change, vol. 72, issue 1, 2019, pp. 9-34, https://doi.org/10.1007/ s10611-019-09836-7; A Efrat, 'Global Efforts against Human Trafficking: The misguided conflation of sex, labor, and organ trafficking', International Studies Perspectives, vol. 17, issue 1, 2016, pp. 34-54, https://doi.org/10.1111/insp.12097. 
grassroots services are often overlooked and under-funded. ${ }^{14}$

The second reason why I think it would be counter-productive to reject antitrafficking wholesale is that it clearly is a powerful tool for securing a seat at the table and winning interest, funding, and sympathy for vital but less obviously 'appealing' issues, like migrants' and workers' rights. In the UK, the nongovernmental organisations Kalayaan and Focus on Labour Exploitation have both proved particularly adept at using trafficking to highlight how restrictive laws and policies around migration and the labour market fuel abuses across the continuum of exploitation. ${ }^{15}$ Internationally, the Global Alliance Against Traffic in Women stands out for its combination of anti-trafficking advocacy, knowledge production and dissemination, and a broader push to improve migrant workers' rights. With mounting evidence as to the ineffectiveness of 'corporate social responsibility'-based measures in tackling labour exploitation, ${ }^{16}$ anti-trafficking might still prove a useful 'hook' to increase support for bottom-up measures that focus on rights over rescue, such as worker-driven social responsibility. An obvious challenge here is overcoming corporations' reluctance to confront how their own business models foster exploitation. ${ }^{17}$

Done well, I think anti-trafficking can — and should — be compatible with efforts to challenge the systems producing everyday abuses. The effective convergence of the two requires, however, some of anti-trafficking's most positive aspects to migrate from the margins to the mainstream. For example, shifts are needed in how trafficking is conceptualised (as part of a broader spectrum of abuse), discussed (sensibly, without recourse to simplistic and sensationalist tropes and shoddy statistics), and addressed (with nuance, disaggregating different issues

14 For more on this issue, see, e.g., E Cockbain and W Tufail, 'Failing Victims, Fuelling Hate: Challenging the harms of the "Muslim grooming gangs" narrative', Race and Class, vol. 61, issue 3, 2020, pp. 3-32, https://doi.org/10.1177/0306396819895727; Smith and Mac.

15 See, e.g., M Ahlberg, 'Hostile Environment Undermines UK Government's AntiSlavery Agenda', Focus on Labour Exploitation, 1 May 2018, retrieved 23 June 2020, https://www.labourexploitation.org/news/hostile-environment-undermines-ukgovernment $\%$ E2\%80\%99s-modern-slavery-agenda; A Sharp and N Sedacca, Dignity Not Destitution: The impact of differential rights of work for migrant domestic workers referred to the national referral mechanism, Kalayaan, London, October 2019, http:/ / www.kalayaan. org.uk/wp-content/uploads/2019/10/Kalayaan_report_October2019.pdf.

16 See, e.g., G LeBaron and A Rühmkorf, 'Steering CSR through Home State Regulation: A comparison of the impact of the UK bribery act and modern slavery act on global supply chain governance', Global Policy, vol. 8, issue S3, 2017, pp. 15-28, https://doi. org/10.1111/1758-5899.12398.

17 See, e.g., G LeBaron, 'Subcontracting Is Not Illegal, but Is It Unethical: Business ethics, forced labor, and economic success', Brown Journal of World Affairs, vol. 20, no. 2, 2014, pp. 237-249. 
and paying attention not just to individuals but also to broader systems and situations that facilitate abuses).

The planning, implementation, and monitoring of anti-trafficking should obviously be responsive to victims and survivors of trafficking. There are also real benefits in being more inclusive of other intersecting populations who have relevant expertise and/or face collateral damage from anti-trafficking, such as collectives of sex workers or domestic workers. At present, anti-trafficking spaces vary greatly in the extent to which they engage with the various constituencies just mentioned. Establishing the trust of those most affected by anti-trafficking means recognising their agency, genuinely listening to their experiences and perspectives, and incorporating their needs into anti-trafficking interventions. Policy-makers, practitioners, activists, and academics alike all need to commit to transparency, rigour, accountability, and ethics in their anti-trafficking work, which should go without saying but has thus far not always been the case. The anti-trafficking field has also long been resistant to evidence that challenges orthodoxies, and there is a stark lack of evaluations, ${ }^{18}$ which makes it too easy to hide agendas, ineffectiveness, and harms. It is important, therefore, to incentivise and invest in more evidence-informed approaches. Overall, it remains to be seen whether there is sufficient appetite within the diverse anti-trafficking field for such changes and challenges to the status quo. Even if the will is there, it may well be difficult to chart a new course while maintaining sufficient political, economic, and social capital to influence policy and practice. Old allies may well be lost and new ones will need to be found. For those genuinely committed to tackling exploitation, however, it is surely a challenge worth seizing.

Acknowledgments: I am grateful to Emily Kenway, Matilda Cockbain and the guest editors for their very helpful comments and suggestions on earlier drafts.

Dr Ella Cockbain is an Associate Professor in Security and Crime Science at University College London (UCL) and a visiting research fellow at Leiden University in the Netherlands. Her research focuses in particular on human

18 D Vigneswaran, 'Methodological Debates in Human Rights Research: A case study of human trafficking in South Africa', in A Bunting and J Quirk (eds.), Contemporary Slavery: Popular rhetoric and political practice, University of British Columbia Press, Vancouver, 2017, pp. 179-201; E Cockbain, K Bowers, and G Dimitrova, 'Human Trafficking for Labour Exploitation: The results of a two-phase systematic review mapping the European evidence base and synthesising key scientific research evidence', Journal of Experimental Criminology, vol. 14, issue 3, 2018, pp. 319-360, https://doi. org/10.1007/s11292-017-9321-3. 
trafficking, child sexual exploitation, and labour exploitation. She has published widely on these topics, including her recent book Offender and Victim Networks in Human Trafficking (Routledge, 2018). She has co-chaired the UK's national working group on preventing 'modern slavery'. Email: e.cockbain@ucl.ac.uk 